Naboka, A.V. (2021). International terrorism activities in the context of globalization. Rethinking of history: conflict of facts and hypotheses. European Scientific e-Journal, 7 (13), 136-144. Hlučín: "Anisiia Tomanek" OSVČ. (in Ukrainian)

Набока, А.В. (2021). Міжнародна терористична Аіяльність в контексті глобалізації. Rethinking of history: conflict of facts and hypotheses. European Scientific e-Journal, 7 (13), 136-144. Hlučín: "Anisiia Tomanek" OSVČ.

\title{
DOI: $10.47451 /$ pol2021-09-001
}

The paper will be published in Crossref, ICI Copernicus, Academic Resource Index ResearchBib, J-Gate, ISI International Scientific Indexing, Zenodo, OpenAIRE, BASE, LORY, LUASA, ADL, eLibrary, and WebArchive databases.

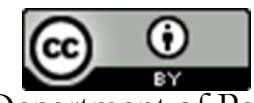

Anton V. Naboka, Graduate Student, Department of Political Science, Philosophy Faculty, Kharkiv V.N. Karazin National University. Kharkiv, Ukraine.

\section{International terrorism activities in the context of globalization}

Abstract: Theses study the features of the phenomenon of international terrorism and its impact on the international political system. The specifics of international terrorism in the age of global turbulence are considered. The world political system is analyzed from the standpoint of geopolitical actors' use of various methods to achieve political goals, including terrorism. The nature and spheres of influence of international terrorism in the modern world are shown. Particular attention is paid to regional and global security in the context of terrorist groups in the Middle East. The article focuses on the activities of the ISIS group and the peculiarities of its functioning in the modern globalized world. The formation of the structure and activity of terrorist groups in the historical context is singled out. The role and principles of international terrorism in the context of geopolitical confrontation are defined.

Keywords: terrorism, globalization, international relations, political system, confrontation, geopolitical influence.

Антон Вадимович Набока, Аспірант, Кафедра політології, Філософський факультет, Харківського національного університету імені В.Н. Каразіна. Харків, Україна.

\section{Міжнародна терористична діяльність в контексті глобалізації}

Анотаиія: В тезах статті досліАжено особливості феномену міжнародного тероризму та його вплив на міжнародну політичну систему. Розглядається специфіка міжнародного тероризму в добу глобальної турбулентності. Аналізується світова політична система з позицій застосування геополітичними акторами різних методів досягнення політичних цілей, зокрема й тероризму. Показано характер та сфери впливу міжнародного тероризму у сучасному світі. Особливу увагу звернено на регіональну та глобальну безпеку в контексті Аіяльності терористичних угрупувань на БАизькому Сході. В центрі уваги статті Аіяльність угрупування IАIА та особливості його функціонування в сучасному глобалізованому світі. Виокремлено формування структури та Аіяльності терористичних угрупувань в історичному контексті. Визначено роль та принципи міжнародного тероризму в контексті геополітичного протиборства.

Ключові слова: тероризм, глобалізація, міжнародні віАносини, політична система, протистояння, геополітичний вплив. 


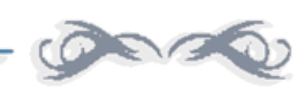

\section{Вступ}

Актуальність теми дослідження. Міжнародний тероризм - це зАочинне діяння яке спрямоване не проти конкретної особи, а проти системи поглядів, що впливає на міжнародні віАносини. Міжнародний тероризм на сьогодні є глобальною проблемою цюдства. Але саме явище тероризму є досить сталим. ВіАомі факти того, що тероризм, як інструмент протилії Аіючим режимам та залякування, існував ще у 19 столітті, зокрема в Російській імперії та Європі. Основною причиною цього явища були нові революційні іАеї та фізична АіквіАація монархів та преАставників уряду.

Об’ект досліАження - Аіяльність міжнародних терористичних угрупувань в контексті глобалізації.

Метою статті є аналіз феномену міжнародного тероризму, змісту та форм діяльності на сучасному етапі, Аослідити особливості впливу міжнародного тероризму на глобальну політичну систему.

Матеріали та методи досліАження. Аیя розкриття теми міжнародного тероризму використані наукові Ажерела. Зокрема особлива увага була приділена захіАним, українським та російським вченим. Теоретичною основою статті $є$ принцип об’єктивності. При написанні статті були використані метод історизму, що дозволив описати міжнародну терористичну Аіяльність 3 точки зору історичного аналізу. Системний метоА АОзволив розглянути міжнародну терористичну Аіяльність як окрему систему взаємодії суб’єктів і об’єктів терористичної діяльності та встановити віАповіАні причинно-насліАкові зв'язки. МетоА синтезу Аозволив проаналізувати різні етапи формування терористичних угрупувань та охарактеризувати ї еволюцію. Вході АосліАження наукової мітератури використано критичний піАхіА. Матеріал структурований та викладений у могічній послідовності та завершеності через застосування хронологічного методу.

Стан наукового вивчення міжнародної терористичної Аіяльності в контексті глобалізації є Аосить високим. АосліАження міжнародного тероризму є Аоволі актуальним питанням як у вітчизняних так і зарубіжних досліАників. Вагомий внесок у Аослілження цієї проблематики внесли такі вчені як Баришніков А.Н., ІАьясов Ф.Н., Б. Ганор, Р. Шольц, К. Бартол та ін.. Міжнародний тероризм найчастіше досліАжується у контексті інструментарію геополітичної боротьби. Незважаючи на достатню актуальність теми феномен міжнародного тероризму потребує уточнень та АосліАжень у сфері протиАіi цьому явищу, через інформаційну добу та виникнення нових загроз.

Практичне значення результатів досліАження полягає у можливості використання матеріалів Аля написання наукових праць.

\section{Результати дослідження}

Поняття міжнародного тероризму з'явилося в 1960-х роках, що можна вважати формою тероризму як такого і має ширше значення та структуру. Аане поняття та його проблематика особливо великого поширення набула на початку 21-го століття. 3 1960-х 
років тероризм мав інші риси та був менш заілеологізований. Зокрема терористичні акти супроводжувались захопленням заручників, мітаків, політичних вбивств. Починаючи 3 кінця 1960-х років найбільш відомою терористичним угрупуванням була «Організація Визволення Палестини» очолюваним Ясиром Арафатом. Боротьба палестинців за створення вцасної держави в $\Lambda$ івані.

На початковому етапі діяльності терористів не було вироблено чітких механізмів боротьби 3 цим явищем. Зокрема угони мітаків та захоплення заручників супроводжувались виконанням вимог зцочинців. На інших етапах протидіï терористичним актам були вироблені механізми боротьби з ними. Зокрема « Аекларація про ліквіАацію міжнародного тероризму» Генеральної Асамблеё ООН в 1994 році, зокрема пункт 1 наголошує: «Государства-члены Организации Объединенных Наций торжественно подтвержАают, что они безоговорочно осуждают как преступные и не имеющие оправдания все акты, методы и практику терроризма, где бы и кем бы они ни осуществАялись, в том числе те, которые ставят поА угрозу Аружественные отношения межАу государствами и народами и угрожают территориальной целостности и безопасности государств» (Аекларация о мерах по миквиАации межАународного терроризма, 1994), а також віАповіАні конвенції про захист ядерної зброї, заручників, протидії фінансуванню тероризму та ін.

Основна мета Ааного явища - це залякати та навести страх на населення. Існує Аекілька десятків визначення поняття «тероризм», проте, одностайної думки немає через те, що присутній фактор сепаратизму, релігійний фактор, фактор нових технологій (3MI) та міжнародного права, зокрема право націй на самовизначення. ИАьясов у своїй статті «Терроризм - от социальных оснований до поведения жертв» зауважує: «Устрашение в методах террористов стало способом управления обществом, и в этих целях межАународный терроризм стремится к циничной и широкой Аемонстрации своих кровавых атак через среАства массовой информации» (Ильясов, 2007).

В понятті міжнародного тероризму можна виділити декілька ознак, зокрема за характером організації можна поділити на:

- організований, що включає в себе чітку ієрархію управління та контроль суб’ектів терористичної Аії, чітку іАейну направленість та створення віАповіАної організації;

- індивідуальний, що передбачає виконання терористичного акту за власними переконаннями або як інструмент Аії організації.

За ідейною направленістю тероризм можна поділити на:

- $\quad$ За релігійним принципом, що передбачає боротьбу та здійснення терористичних дій 3 метою боротьби за релігію, так званий ісламський фактор;

- Національна складова, що супроводжується боротьбою за національно-визвольні ідею та сепаратизм.

Починаючи 311 вересня 2001 року та терористичного акту в Нью-Йорку міжнародний тероризм набуває глобального характеру, також якісно віАрізняється своєю організацією. Баришніков з цього приводу наголошує, що «таким образом, побочные эффекты глобализации обнаружили свои опасные стороны, и Аля многих стало очевидно, что борьба с межАународной преступностью и ее высшим проявлением - 
сетью транснациональных сплоченных и хорошо оснащенных террористических организаций - в ближайшее время станет приоритетом номер один в мировой политике» (Барышников, 2006). Того ж року Радою Безпеки ООН був заснований «комітет по боротьбі з тероризмом». Найбільш впливовою манкою міжнародного тероризму є опора на ісламсько-екстримістьскі угрупування, метою яких $є$ дестабілізація роботи міжнародного співтовариства, спонукання до хаосу, залякування населення, порушення громадського порядку, дестабілізація міжнародної політичної системи.

Особливого розмаху міжнародний тероризм Аосяг після створення таких

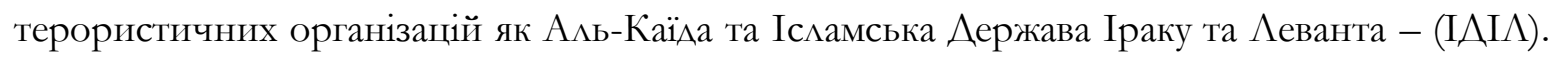
Хоча Аль-КаїАа була створена ще в 1980-х роках вона і залишається однією із найвпливовіших терористичних організацій у світі. Зокрема саме цю організацію звинувачують в теракті 11 вересня 2001 року в США. Ця терористична організація складається $з$ представників ваххабітського направлення ісламу з якими вів боротьбу СРСР 3 1979-1989, що віАрізняється віА інших більш жорсткими методами боротьби та впровадженням Шаріату у повсякденному житті.

Варто зауважити, що США забезпечували ваххабітів озброєнням та фінансуванням, залия геополітичного домінування на Близькому Сході, але після чого Аії терористів були спрямовані проти арміі США. Потрібно зауважити, що спеціальні служби США зокрема ЦРУ були пілдані критиці за вілповіАні Аії (особливо після 11 вересня 2001 року). Після чого було оголошено «Війну $з$ тероризмом».

На сучасному рівні технологічного розвитку міжнародний тероризм вийшов на новий етап. Важливим фактором у сприянні цьому - стали Аії IАI $\Lambda$, що змогли створити ознаки державного утворення. Ця терористична організація оголосила «Всесвітній Халіфрат», що несе за собою руйнування світських режимів в ісламських державах. На початковому етапі - це країни, що охоплює території Близького Сходу та Північної Африки. Це угрупування примусово насаджує закони Шаріату, де фактично вілсутні права жінок, а також присутнє рабство. IАI $\Lambda$ вАацося поглинути інші терористичні угрупування, що сприяло консолілації ісламського-екстимістського крила. Наявність фінансування, матеріально-технічного засобів, торгівлі нафтою, вербовки каАрів, впроваАження комп'ютерних технологій дало змогу чітко структурувати організацію та піАвищити іï ефективність. Важливою особливістю є те, що IАI $\Lambda$ активно розвивається в мережі Інтернет і розширює сфери впливу та усклаАнює боротьбу 3 ними. Потужним фундаментом інтелектуальної активності IАI $\Lambda$ є висококваліфіковані фахівці, що зАобули освіту в Европі (особливо у сфері IT), а потім присягнули на вірність IАІ $А$. Це ми можемо побачити за якісним телевізійним супроводженням масових страт, у вигляді голмівудського фільму, що Аля захіАного глядача є шоком.

Безперечно, міжнародний тероризм є загрозою Аля світової цивілізації, але існує припущення, що це явище може бути елементом гібридної війни, та в деякій мірі, є контрольованим. Зокрема Кісінджер наголошує: «Региональные державы направляли в Сирию оружие, финансы и материально-техническую помощь на благо «своих»: Саудовская Аравия и страны Персилского залива снабжали суннитов; Иран подАерживал Асада через «Хезболиу». КогАа боевые действия зашли в тупик, все чаще стали прояв ять себя радикальные группы, которые творили чудовищные зверства, напрочь игнорируя 
«прекраснодушные разговоры» о правах человека» (Киссинжер, 2018). Ситуація вигляАає гіршою якщо ці організації створені та фінансуються з конкретною метою, але вийшли 3-піА контролю. Можна висунути припущення, що вілбулася комерціоналізація тероризму як інструменту геополітичної боротьби.

Якщо провести історичні аналогії, то таких масштабних Аій та терористичної активності в Свропі не було до цього часу. Країни Заходу активно створюють програми боротьби та протилії тероризму на Близькому Сході, але кількість та прояви терористичних актів навпаки збільшується. Загострює боротьбу з сучасним тероризмом те, що на перше місце виходять не матеріальні ресурси, а іАеологічні. Зокрема в ЗахіАній Європі кількість мігрантів з Близького Сходу Аосить велика за останні роки, насліАком чого виникла криза іАентичності та загострило проблему виявлення потенційно небезпечних «елементів». Мігранти з Близького Сходу становлять небезпеку, тому уряди Аеяких європейських країн мають на меті встановити на кордоні паркани Аля стримування біженців.

Ще більшу небезпеку становлять громадяни європейських країн, які емігрували в 1980-х роках до Європи, але не змогли асимілюватись. Аеякі поселення у Франції, зокрема Прованс мають рівень такого населення до 70\%. IАI $\Lambda$ зі свого боку використовує сучасні технології Аля пропаганди радикального ісламу. Це набагато спрощує піАготовку потенційних терористів-смертників Аля терористичних актів. Спеціальні служби європейських країн не завжди зАатні попередити загрозу терористичного акту через те, що ці громаАяни є «сплячими терористами». АіАерами терористичних рухів зАійснюється активна вербовка радикальних громадян, особлива увага приділясться молодому поколінню та Аітям.

Скцадність в боротьбі з тероризмом полягає в тому, що інструментарій терору є дуже широким: віА мережевого впливу Ао застосування зброї. Мережевий принцип терористичної діяльності Аозволяє формувати комірки радикальних елементів практично на всіх континентах. Тому можна припустити, що I $\triangle \mathrm{I} \Lambda$ це не організація, а терористична квазі-держава, що у своєму розпорядженні має піАготовлену армію, а також політичне управління, торгів ю, вцасну еліту, тренувальні табори та навіть зброю масового враження.

Проте в глобальній політиці будь-яка дія не може виникнути сама по собі. Кожен елемент політичної Аіє має свої причинно-насліАкові зв'язки. Після початку громадянської війни в Сирії 2011 року та піАтримки США опозиційних сил Сирії кількість зброї на цій території зросла. Проте важко розділити преАставників опозиції віА терористів. Представники Саудівської Аравії та Катару, прагнучи подолати режим Башара Асада в Сирії та регіонального домінування в регіоні забезпечують фінансами та озброєнням різні угрупування. Тому явище тероризму є, в деякій мірі, контрольованим явищем. Через те, що віАсутність фінансування знизить можливості терористів.

Міжнародне співтовариство закликає до боротьби з тероризмом, але не може виробити чіткої стратегії. НаприклаА, ОБСЕ наголошує на тому, що «терроризм намерен подорвать те самые ценности, которые объединяют ОБСЕ. В то же время государстваучастники однозначно отвергают связь терроризма с какой-Аибо конкретной расой, национальностью или религией. Поэтому Организация преисполнена решимости в 
принятии эффективных мер по предотвращению терроризма и борьбе с ним во всех его формах и проявлениях как с серьезным преступлением, не имеющим никакого оправдания, какими бы ни были его мотивы или происхожАение» (ОБСЕ. Боръба с терроризмом, 2017). Прем’єр-міністр Великої Британії та президент США, зокрема Тоні Блер та Барак Обама визнали помилковою ідею вторгнення до Іраку у 2003 році наслідком чого стало формування IАI $\Lambda$. Терористична Аіяльність може бути використана як механізм впливу і дестабілізації в регіонах Близького Сходу, особливо якщо терористів можна поділити на «соїх» та «чужих». ЗгіАно з Ю.В. Самовичем «Особая опасность межАународного терроризма состоит в том, что по существу он составАяет акт косвенной агрессии, который маскируется под независимые Аействия отАельных Аиц или групп Аиц» (Самович, 2012).

Внаслідок консоліАації міжнародних сиц зокрема Росії та США був міквідований мілер

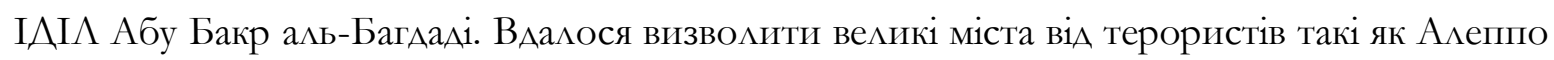
та Ер-Ракки, де була найбільша концентрація зброї та живої сили противника. Після чого терористична Аіяльність пішла на спад. А^е терористична Аіяльність може перейти в іншу фазу після виводу американських військ в Афганістані та захопленням вцади угрупуванням Талібан.

\section{Обговорення}

Загалом автор не претендує на остаточне розкриття зазначеної теми, піАкреслюючи, що кожен $з$ розглянутих аспектів може бути предметом обговорення й подальшого грунтовного АосліАження, з'ясування й уточнення окремих фактів. Поняття міжнародного тероризму є досить широким та має чіткі структурні піАрозАіли, що вкАючає в себе Ажерела фінансування, мету, завдання, функції. Слід зауважити, що це питання потребує ширшого обговорення особливо у питанні фінансування міжнародного тероризму. Зокрема можна розглянути приклаА Талібану. Особливу увагу варто приділити терористичним ватажкам та їх впливу на Аіяльність угрупувань. Важливим чинником залишається питання іАеології тероризму. Тому в подальшому є можливість Аля науковців розширити проблематику міжнародного тероризму.

\section{Висновки}

Отже терористична Аіяльність - це цілеспрямована система насильницьких радикальних Аій (вибухів, вбивств) Аля впливу на свідомість населення 3 метою залякування, впливу на офіційні органи влади з метою виконання віАповідних умов. Тобто чіткоїборотьби проти тероризму як фактора зла унеможливлюють геополітичні інтереси, а тероризм може стати фактором контролю в регіоні або приводом до вторгнення в Аержаву.

Міжнародний тероризм є однією з найважливіших глобальних проблем Аюдства через тотальний вплив на свідомість громадян на всіх континентах. Міжнародне співтовариство активно бореться з проявами тероризму та розширює антитерористичні заходи, але потрібна більш тісна консолідація та обмін досвідом. Така діяльність зумовлена 
широким спектром інструментарію терористів. Основною особливістю сучасної боротьби з тероризмом є кібербезпека та захист персональних даних.

\section{Список Ажерем інформації:}

Аекцарация о мерах по Аиквидации международного терроризма (1994, 9 грудня). Отримано 05.07.2021

https://www.un.org/ru/documents/decl conv/declarations/terrdec1.shtml

Ильясов, Ф.Н. (2007). Терроризм - от социальных оснований до поведения жертв. Сочиологические исследования, 6, 78-85.

Барышников, А.Н. (2006, 28 березня). Международный терроризм в условиях глобализации. Отримано 21.08.2021 за http://anthropology.ru/ru/person/baryshnikov$\underline{\mathrm{dn}}$

Киссинджер, Г. (2018). Мировой порядок. (пер. В. Желнинов, А. Милюков) Москва: АСТ.

ОБСЕ. Борьба с терроризмом (2017, 10 січня). Отримано 22.08 .2021 за https://www.osce.org/ru/countering-terrorism

Самович, Ю.В. (2012). О понятии «межАународный терроризм». Вестник Томского государственного универстета, 361, 120-123. 